\title{
Okullarda Sosyal Adalet Liderliği: Bir Karma Yöntem Çalışması
}

\author{
Social Justice Leadership in Schools: A Study of Mixed Methods
}

Muhammet İbrahim AKYÜREK (iD , Dr., Etimesgut Bilim ve Sanat Merkezi, i_akyurek56@hotmail.com

\begin{abstract}
Akyürek, M. İ. (2021). Okullarda sosyal adalet liderliği: Bir karma yöntem çalışması. Batı Anadolu Eğitim Bilimleri Dergisi, 12(2), 515-535.
\end{abstract}

Geliş tarihi: 25.12 .2020

Kabul tarihi:04.10.2021

Yayımlanma tarihi:28.12.2021

Öz. Araştırmanın amacı; öğretmen algılarına göre, okullardaki sosyal adalet liderliğinin durumunu belirlemektir. Bu araştırma, karma yöntem araştırma desenleri arasında yer alan yakınsayan paralel desen (çeşitleme/birleştirme deseni) biçimindedir. Araştırmanın çalışma grubunu Ankara il merkezindeki resmi örgün eğitim kurumlarında görevli öğretmenler oluşturmaktadır. Nicel verilerin toplanması için, "Sosyal Adalet Liderliği Ölçeği"; nitel verilerin toplanması için, görüşme yapmak amacıyla araştırmacı tarafından geliştirilmiş "Görüşme formu" kullanılmıştır. Uygulamalar; araştırmacı tarafından, okul yönetimi ve öğretmenlerin gönüllülüğü dikkate alınarak, örneklem listesi doğrultusunda her bir okulda uygulamaya katılan öğretmenlerle görüşülerek, ölçme aracı hakkında bilgi verilmesi ile birlikte gerçekleştirilmiştir. Demografik değişkenlere ilişkin araştırma sonuçları incelendiğinde; öğretmenlerin okul yöneticilerinin sosyal adalet liderliği düzeyine ilişkin algıları, cinsiyet, medeni durum, yaş ve öğrenim durumu değişkenlerine göre anlamlı bir farklılık göstermiştir. Ayrıca gerçekleştirilen görüşme sonucunda; özellikle okul yöneticilerindeki sosyal adalet durumunun önemi ortaya çıkmıştır. Araştırmada, okullarda sosyal adalet liderliği ve bu kapsamdaki destek, eleştirel bilinç ve katılımın yeterli olduğu bulunmuştur. Bu olumlu gidişatın devam etmesi ve artması için tüm eğitim paydaşlarını bilinçlendirici eğitimler düzenlenebilir. Toplumda dezavantajlı olan kesimlerle okullarda birtakım ortak etkinlikler düzenlenerek, etkin bir sosyal adalet liderliği sağlanabilir.

Anahtar Kelimeler: Sosyal adalet, Sosyal adalet liderliği, Okul, Okul yöneticisi, Öğretmen.

Abstract. Purpose of the research; to determine the status of social justice leadership in schools according to teachers' perceptions. This research is in the form of convergent parallel pattern (diversification/combining pattern) which is among the mixed method research designs. The working group of the research consists of teachers working in formal education institutions in Ankara city center. "Social Justice Leadership Scale" for collecting quantitative data; In order to collect qualitative data, "Interview form" developed by the researcher was used for interview. Apps; It was carried out by the researcher, taking into account the volunteering of the school management and teachers, interviewing the teachers who participated in the practice in each school in line with the sample list, and providing information about the measurement tool. When the research results regarding demographic variables are examined; Teachers 'perceptions of school administrators' level of social justice leadership showed a significant difference according to the variables of gender, marital status, age and educational status. In addition, as a result of the meeting; In particular, the importance of social justice in school administrators has emerged. In the research, it was found that social justice leadership and support, critical awareness and participation in this context are sufficient in schools. Awareness-raising trainings can be organized for all education stakeholders in order to continue and increase this positive trend. By organizing some joint activities at schools with the disadvantaged segments of the society, an effective social justice leadership can be achieved.

Keywords: Social justice, Social justice leadership, School, School administrator, Teacher. 


\section{Extended Abstract}

Introduction. Trust-based relationships can be established in schools through the provision of social justice. In this way, a qualified education and training environment can be created. In this environment, it may be easier for all education stakeholders to collaborate. In this process, managers who can lead the provision of social justice are needed. School administrators' having the competencies to provide social justice can enable them to be an effective social justice leader. Although there are studies examining social justice leadership in schools in the literature, there are not many studies conducted with mixed method design. In this respect, study; It will be able to provide educational stakeholders, especially school administrators, with a diverse and rich perspective and contribute to the leadership of social justice in schools. Also, this study; will be able to fill the research gap based on the variety of methods and patterns in social justice leadership. In this context, the purpose of the research is; to determine the status of social justice leadership in schools according to teachers' perceptions.

Method. This research is in the form of converging parallel pattern (diversification / combining pattern) which is among mixed method research designs. In this context, in the research; The extent to which the responses of teachers and school administrators about social justice leadership are compatible with the views of social justice leadership was examined. The working group of the research consists of teachers working in formal education institutions in Ankara city center. In this study, 436 teachers selected randomly from the districts of Ankara city center were included in the study. In addition, in order to collect qualitative data as the same level participant, the participants were determined through analogous case sampling from among the teachers working in Ankara city center. In this study, 20 teachers from the districts in the city center of Ankara were included in the study. In this study, two different data collection tools were used. "Social Justice Leadership Scale (SALÖ)" developed by Özdemir and Kütküt (2015) for collecting quantitative data; In order to collect qualitative data, "Interview form" developed by the researcher was used for interview. The measurement tool used in the study, the scale usage permission obtained from Özdemir and Kütküt (2015) and the legal permit obtained from the Ankara Provincial Directorate of National Education were visited to the schools within the scope of the sample, and between the dates of 27-31 August 2020 in the 2019-2020 academic year. head teacher during the seminar period). Apps; It was carried out by the researcher, taking into account the volunteering of the school management and teachers, interviewing the teachers who participated in the practice in each school in line with the sample list, and providing information about the measurement tool. Interviews were conducted face to face for 15-30 minutes. The quantitative and qualitative data sets collected from two different sources were collected independently. In line with the analysis of the data; quantitative and qualitative data were analyzed separately.

Results. When considered in general, it was seen that teachers' perceptions of the social justice leadership level of school administrators were at the level of agree. In addition, there are answers of the teachers regarding the social justice leadership status of school administrators mostly regarding the social justice. Together, these two findings (quantitative and qualitative) point to the existence of leadership in terms of social justice in schools and the findings support each other.

Discussion and Conclusion. When considered in the support dimension, it was seen that teachers' perceptions of the support level of school administrators were at the level of I agree. In addition, the answers of the teachers regarding the support status of the school administrators are mostly positive. Together, these two findings (quantitative and qualitative) point to the existence of a social justice leadership in terms of providing support in schools and the findings support each other. When considered in the critical awareness dimension, it was seen that teachers 'perceptions of school administrators' support level were at the level of agree. In addition, there are answers of the 
teachers regarding the fact that they mostly provide a positive support regarding the critical consciousness of school administrators. Together, these two findings (quantitative and qualitative) point to the existence of a social justice leadership in terms of providing critical awareness in schools and the findings support each other. When considered in the dimension of participation, it was seen that teachers' perceptions of the support level of school administrators were at the level of agree. In addition, there are answers of teachers regarding the fact that they mostly provide positive support regarding the participation status of school administrators. Together, these two findings (quantitative and qualitative) point to the existence of a social justice leadership in terms of ensuring participation in schools, and the findings support each other. According to teachers' views, social justice leadership in schools is/is at a sufficient level. School administrators show leadership qualities in a necessary way in the context of ensuring social justice. This indicates that an effective social justice mechanism has been established in schools and that administrators play an active role in this issue. Administrators ensure social justice and equality in schools. The research finding is similar to the findings of the research conducted by Özdemir and Pektaş (2017), Bozkurt (2018) and Arslan (2019). In addition, in the studies conducted by Bozdoğan and Sağnak (2011), Taş and Çetiner (2011), Turhan and Çelik (2011), Gündüz and Balyer (2012), it was determined that school administrators exhibited leadership oriented behaviors at a high level. Previous studies indicated that the principal, as the leader of social justice, supported and supported students and teachers in need (Theoharis, 2008). In another study, it was determined that school principals, as social justice leaders, establish a relationship based on trust with the school community and make an effort to raise the awareness of the school community to realize social inequalities (Furman, 2012). In the studies conducted by Özdemir (2017), Büyükgöze, Şayır, Gülcemal, and Kubilay (2018) and Gören (2019) on social justice leadership, it was determined that school administrators displayed social justice leadership behavior at a moderate level. This may be due to the difference in the sample group used in the studies. 


\section{Giriş}

Eğitime erişim sürecinde okullarda birtakım toplumsal, etnik, cinsiyet ve sınıf bazlı eşitsizlikler yaşanmaktadır (Archer, Hutchings ve Ross, 2003; McWhirter, 1997). Toplumdaki eşitsizliklerin tarihi, politik, ekonomik, toplumsal ve kültürel temelleri söz konusudur (Hurst, 2012). Toplumsal eşitsizliklerle mücadele, yirminci yüzyılda hız kazanmıştır. Bu bağlamda, özellikle íkinci Dünya Savaşı sonrasında, devlet sosyal adaleti sağlamak amacıyla refah artırıcı uygulama ve politikaları hayata geçirmiştir (Jordan, 1998). Sosyal adalet; fırsat eşitliği, haklar, çeşitlilik, eşitlik gibi bazı toplumsal süreçleri içerisine alan bir kavramdır. Politik olarak sosyal adaletin; dağıtımcı, ilişkisel ve kültürel olmak üzere üç türü bulunmaktadır. Dağıtımcı adalet, toplumsal varlıkların toplumu oluşturan her gruba hakkaniyete bağlı olarak paylaştırılması durumudur. ilişkisel adalet, marjinal toplumsal grupların kendilerini ilgilendiren bazı kararlara katılımını içerir. Kültürel adalet ise toplumu oluşturan alt-kültürler arasındaki eşitliğin sağlanmasıdır (Gewirtz ve Cribb, 2002). Sosyal adalet düşüncesi, kendini "öteki" olarak algılayan toplumsal grupların toplumla bütünleşmeleri gerektiğini belirten bir ifade biçiminde gelişmektedir (Gewirtz, 1998).

Sosyal adaletin öneminin artmasıyla birlikte kamusal alanlar, iş ortamları, eğitim örgütleri gibi pek çok alanda sosyal adaletin sağlanması öncelikli amaçlardan biri durumuna gelmiştir. Bu konuda liderlere bazı önemli sorumluluklar yüklenmektedir. Toplum ve topluluklarda adaletli olması istenen en önemli kişiler liderlerdir. Liderlerin adil davranışları, toplum ve topluluk üyelerinin davranışlarında etkili olmaktadır (Bozkurt, 2018). Fraser (2012)'e göre sosyal adalet liderliği; en umutsuz durumlarda bile herkesi başarı ve iyiye götürmek için ortamları değiştirecek kişinin liderlik uygulamalarındaki etkinliği destekleyen bir liderlik türüdür. Sosyal adalet ve sosyal adalet liderliği eğitim ortamlarında da niteliğin artırıması, örgütsel ve bireysel gelişimin sağlanması bağlamında büyük bir önem arz etmektedir.

Sosyal adaletin eğitim ortamlarındaki durumu, uzun süredir eğitim sosyologları tarafından tartışılmaktadır. Okullarda sosyal adaletin sağlanması sürecinde okul müdürünün rolü ise 2000 'li yıllarda akademik çevrelerce tartışılmaya başlanmıştır (Oplatka, 2010). Okullarda bu kapsamdaki çalışmalar sosyal adalet ve liderlik ilişkisini; çok kültürlü, feminist, Latin ve Afro-Amerikan liderlik yaklaşımlarını içeren eleştirel yaklaşımlar odağında analiz etmektedir (Furman ve Gruenewald, 2004; McCabe ve McCarthy, 2005). Bu doğrultuda sosyal adalet liderliğinin tanımları farklılık göstermiştir. Marshall ve Oliva (2006) tarafından sosyal adalet liderliği; okullarda başarı gösteremeyen azınlık, kadın ve ekonomik açıdan dezavantajılıarın başarılarını artırmaya odaklı bir liderlik olarak tanımlanmıştır. Theoharis (2007) tarafından ise sosyal adalet liderleri; ırkları, sınıfları, cinsiyetleri ve engellilikleri nedeniyle tarih boyunca ötekileştirilmiş/ötekileştirilmeye devam edilen grupların yanında bulunarak bu durumu liderlik vizyonlarının ve uygulamalarının merkezine yerleştiren kişiler olarak belirtilmiştir.

Sosyal adalet liderliğine odaklanan çalışmalar, kavramın üç boyutlu bir yapı olduğunu belirtmektedir (Özdemir ve Kütküt, 2015). Sosyal adalet liderliğinin ilk boyutu "destek"tir. Destek boyutu kapsamında okul müdürleri, okullarda dezavantajlı öğrencilerin eğitim imkânlarından en fazla düzeyde yararlanabilmelerine dönük çaba harcar. Sosyal adalet lideri olarak okul müdürünün temel bir görevi, özellikle dezavantajlı öğrencileri destekleyerek onların akademik başarılarını artırmaktır. Bu amaçla, okul müdürü okullarda öğrencilerin zenginleştirilmiş eğitim programlarından en fazla düzeyde yararlanabilmelerinin yollarını araştırır (Oakes, Quartz, Ryan ve Lipton, 2000). Alanyazın incelemesinde, zengin kapsamlı programlara erişimde birtakım zorluklar yaşayan dezavantajı öğrencilerin akademik gelişimlerinin de nispeten düşük olduğu belirtilmektedir (Brown, 2006). 
Sosyal adalet liderliğinin ikinci boyutu "eleştirel bilinç"tir. Eleştirel bilinç; sosyal adalet lideri olarak okul müdürünün dışlama ve toplumsal baskı konusunda eleştirel bir dünya görüşüne sahip olmasını ifade etmektedir (Brooks ve Miles, 2006). Freire (2005)'e göre eleştirel bilinç; toplumsal, siyasal ve ekonomik çelişkilerin fark edilmesi ve bu farkındalığa bağlı olarak bu çelişkilerle mücadele edilmesini kapsamaktadır. Bu kavramsallaştırma kapsamında; eleştirel bilince sahip bir okul müdürü toplumsal eşitsizliklere ilişkin bir görüş açısına sahiptir. Toplumsal eşitsizliklerin farkına varan okul müdürü, bu görüş açısını öğrencilere de kazandırmak için çaba göstererek onların da eleştirel bir bilince sahip olmaları için etkin bir biçimde çalışır (McKenzie vd., 2008).

Sosyal adalet liderliğinin son boyutu ise "kapsama (inclusion)"dır. Kapsayıcı uygulamalardaki amaç; dezavantajlı öğrencileri nispeten avantajlı öğrenciler ile bir araya getirerek, onların da nitelikli eğitim imkânlarından faydalanabilmelerini sağlamaktır. Bu şekilde eğitime erişim bağlamında tüm öğrenciler arasında hakkaniyetin sağlanmasına uğraşılmaktadır (Katzman, 2007). Bunu gerçekleştirebilmek amacıyla sosyal adalet lideri olarak okul müdürü, okullarda sınıf ve şubeleri oluştururken farklı nitelikteki öğrencileri bir araya getirerek sınıf ve şubelerde bir çeşitlilik sağlamaktadır (DeMatthews ve Mawhinney, 2014). Böylece okullarda homojen sınıf ve şubeler yerine farklı gereksinimleri olan öğrencilerin benzer eğitim imkânlarından faydalanabilmelerine imkân tanıyan heterojen sınıf ve şubeler oluşturulmaktadır. Bu hususta yürütülmüş bir araştırmada özel eğitime ihtiyacı olan çocukların, akranları ile birlikte normal sınıflarda eğitim almalarının onların başarılarını artırdığı belirlenmiştir (Baker, Wang ve Walberg, 1995). Bu gelişmelerin sağlanmasında etkin bir sosyal adalet liderliği sergilemek önemlidir.

Sosyal adalet liderliğine yönelik akademik ilgi artmaktadır. Bunun bir nedeni, mevcut toplumsal eşitsizliklerin okullarda yeniden üretildiğine yönelik olan eleştirel yaklaşımlardır (Bourdieu ve Passeron, 1990). Bu bağlamda nitelikli bir eğitime erişimin etnik yapı, sosyal sınıf ve cinsiyetle ilişkili olduğu belirtilmektedir (Archer vd., 2003; McWhirter, 1997). Sosyal adalet lideri olarak okul müdürünün görevi ise toplumsal eşitsizliklerin okul ortamındaki etkilerini en aza indirmek ve dezavantajlı grupların eğitim imkânlarından en fazla yararlanmalarını desteklemektir. Okullarda sosyal adalet liderliği, dezavantajlı grupların okula dönük bağ|ılıklarının artırılarak akademik gelişimlerinin desteklenmesidir. Yapılan bir araştırmada dezavantajı öğrencilerin okul başarıları düşük bulunmuştur (Finn, 1993). Dezavantajlı öğrencilerin akademik başarılarının düşük olmasının önemli bir nedeni okul bağlılıklarının düşük bir düzeyde kalmasıdır (Finn ve Rock, 1997).

Alanyazında sosyal adalet lideri niteliğine sahip okul yöneticileri hakkında birtakım araştırmalar yapılmıştır. Bu araştırmalardan birini gerçekleştiren Theoharis (2008), sosyal adalet liderlerinin okulda hak ve adaleti sağlamaya çalıştıklarını, görevlerini büyük bir tutku ile yerine getirdiklerini, alçak gönüllü bir yapıya sahip olduklarını, öğrenci intiyaçlarını öncelikli iş olarak gördüklerini, okulun rutin işlerine oranla daha çok sahip oldukları vizyonun peşinden koştuklarını ve bildikleri yoldan ilerlediklerini belirlemiştir. Furman (2012) ise, sosyal adalet lideri niteliklerine sahip yöneticilerin okul paydaşları ile güvene bağlı bir ilişki yürüttüklerini, katılımcı ve demokratik olduklarını, öğretmen ve öğrencilere toplumsal eşitsizlikler hakkında farkındalık kazandırılması doğrultusunda bilinçlendirme çalışmaları yaptıklarını, okulda topluluk duygusunu öncelediklerini ve eğitim ortamlarını geliştirmek için uğraştıklarını tespit etmiştir.

Okullarda sosyal adaletin sağlanması yoluyla okullarda güvene dayalı ilişkiler kurulabilir. Bu şekilde nitelikli bir eğitim öğretim ortamı oluşturulabilir. Bu ortamda tüm eğitim paydaşlarının işbirliği halinde çalışması kolaylaşabilir. Bu süreçte sosyal adaletin sağlanmasına liderlik edebilecek yöneticilere ihtiyaç vardır. Okul yöneticilerinin sosyal adaleti sağlamaya dönük yeterliliklere sahip olmaları etkili bir sosyal adalet lideri olmalarını sağlayabilir. 
Alanyazında okullarda sosyal adalet liderliğini inceleyen çalışmalar bulunmasına rağmen, karma yöntem deseniyle yapılan çalışmalara rastlanamamıştır. Bu açıdan, çalışma; eğitim alanı uzmanlarına, başta okul yöneticilerine olmak üzere eğitim paydaşlarına okullarda sosyal adalet liderliğinin sağlanması hususunda çeşitli ve zengin bir bakış açısı kazandırması ve katkıda bulunması beklenmektedir. Ayrıca, bu çalışma; sosyal adalet liderliği konusundaki yöntem ve desen çeşitliliğine dayalı araştırma boşluğunu giderebilecektir. Bu kapsamda, araştırmanın amacı; öğretmen algılarına göre, okullardaki sosyal adalet liderliğinin durumunu belirlemektir. Araştırma amacına bağlı olarak, araştırma sorusu şu şekildedir:

$>$ Öğretmenlerin; okul yöneticilerinin sosyal adalet liderliğine ilişkin cevapları, sosyal adalet liderliği algıları ile ne derece uyumludur?

\section{Yöntem}

$\mathrm{Bu}$ bölümde; araştırmanın deseni, çalışma grubu ve katılımcılar, veri toplama araçları, verilerin toplanması ve analizine yer verilmiştir.

\section{Araştırmanın deseni}

Bu araştırma, karma yöntem araştırma desenleri arasında yer alan yakınsayan paralel desen (çeşitleme/birleştirme deseni) biçimindedir. Yakınsayan paralel desen, araştırmacının nicel ve nitel aşamaları araştırma sürecinin aynı olan bir aşamasında eş zamanlı şekilde uygulamasıyla oluşur. Bu desen yöntemlere eşit öncelik vererek çözümleme sırasında bu aşamaları birbirinden ayrı tutar ve sonrasında genel yorumlama yaparken sonuçları birleştirir. Yakınsayan desenin amacı, araştırma problemini en iyi bir biçimde anlamak için "aynı konu üzerinde farklı fakat birbirini tamamlayıcı veri toplamak"tır. Yakınsayan desende dört ana adım bulunmaktadır. İlk olarak, araştırmacı ilgi konusuna göre hem nitel hem de nicel veri toplar. Veri toplamanın bu iki türü, eş zamanlı fakat ayrıdır yani biri diğerinin sonucuna dayanmaz. Ayrıca çalışmanın araştırma sorularına ulaşmak için eşit önem arz eder. İkinci olarak, araştırmacı tipik nitel ve nicel analitik prosedürler kullanarak iki araştırmanın verilerini birbirlerinden ayrı olarak analiz eder. Bu iki küme sonuç elde edildiğinde, araştırmacı ara yüz noktasına erişir ve iki küme sonucunu üçüncü bir adımda birleştirmek için çalışır. Bu birleştirme aşaması doğrudan birbirinden bağımsız sonuçları karşılaştırma ya da yeni analizler sırasında iki veri türünü ilişkilendirmeyi kolaylaştırmak amacıyla sonuçları dönüştürmekten oluşur. Son adımda, araştırmacı iki sonuç kümesinin hangi ölçüde ve yollarda birleştiğini, ayrıldığını, ilişkili olduğunu yorumlar ve/veya çalışmanın genel amacına cevap olacak biçimde daha iyi bir anlama oluşturmak için bunları birleştirir (Creswell ve Clark, 2018). Bu bağlamda, araştırmada; öğretmenlerin, okul yöneticilerinin sosyal adalet liderliğine ilişkin cevaplarının, sosyal adalet liderliği görüşleri ile ne derece uyumlu olduğu incelenmiştir.

\section{Çalışma grubu ve katılımcılar}

Araştırmanın çalışma grubunu Ankara il merkezindeki resmi örgün eğitim kurumlarında görevli öğretmenler oluşturmaktadır. Örneklem aynı veya farklı kişilerden meydana gelebilir. Örneklem büyüklüğü olarak ise; nicel örneklemden daha küçük örnekleme sahip olan nitel araştırmalarda, farklı büyüklüklere sahip iki örneklem iyi bir düşüncedir (Creswell ve Clark, 2018). Bu araştırmada, aynı düzeydeki katılımcı olarak nicel veri toplamak için Ankara il merkezinde görevli öğretmenler arasından basit rastlantısal örnekleme yoluyla katılımcılar belirlenmiştir. Ankara ilinde toplam 55 bin öğretmen görevlidir (Milli Eğitim Bakanlığı [MEB], 2020). Bu araştırmada Ankara il merkezindeki ilçelerden (Altındağ, Çankaya, Etimesgut, Gölbaşı, Keçiören, Mamak, Pursaklar, Sincan, Yenimahalle) seçkisiz olarak belirlenen 436 öğretmen (okul öncesi, ilkokul, ortaokul ve lise) çalışmaya 
dâhil edilmiştir. Ayrıca, aynı düzeydeki katılımcı olarak nitel veri toplamak için Ankara il merkezinde görevli öğretmenler arasından benzeşik durum örneklemesi yoluyla katılımcılar belirlenmiştir. Bu araştırmada Ankara il merkezindeki ilçelerden benzeşik durum örneklemesi ile belirlenen 20 öğretmen çalışmaya dâhil edilmiştir.

Nicel veri toplamak için araştırmaya dâhil edilen öğretmenlerin demografik özelliklerine ilişkin bilgilerine aşağıdaki tabloda yer verilmiştir.

Tablo 1.

Demografik değişkenlere göre frekans ve yüzde dağııımları

\begin{tabular}{llrr}
\hline Değişken & & $\mathbf{n}$ & \% \\
\hline Cinsiyet & Kadın & 320 & 73.4 \\
& Erkek & 116 & 26.6 \\
\hline Medeni durum & Evli & 396 & 90.8 \\
& Bekâr & 40 & 9.2 \\
\hline Yaş & $21-30$ & 16 & 3.7 \\
& $31-40$ & 228 & 52.3 \\
& $41-50$ & 148 & 33.9 \\
& L1 ve üzeri & 44 & 10.1 \\
\hline Öğrenim durumu & Lisans & 400 & 91.7 \\
& Lisansüstü & 36 & 8.3 \\
\hline Toplam & & 436 & 100 \\
\hline
\end{tabular}

Tablo incelendiğinde; cinsiyet değişkenine göre oran olarak kadınların \%73.4 ile, erkeklere göre daha fazla olduğu görülmektedir. Medeni durum değişkenine göre oran olarak evli olanların \%90.8 ile, bekâr olanlara göre daha fazla olduğu görülmektedir. Yaş değişkenine göre en fazla orana sahip grubu \%52.3 ile 31-40, en az orana sahip grubu ise \%3.7 ile 21-30 yaş grubu oluşturmaktadır. Öğrenim durumu değişkenine göre oran olarak lisans mezunu olanların \%91.7 ile, lisansüstü mezunu olanlara göre daha fazla olduğu görülmektedir.

\section{Veri toplama araçları}

Bu araştırmada, iki farklı veri toplama aracı kullanılmıştır. Nicel verilerin toplanması için, Özdemir ve Kütküt (2015) tarafından geliştirilmiş olan "Sosyal Adalet Liderliği Ölçeği (SALÖ)"; nitel verilerin toplanması için, görüşme yapmak amacıyla araştırmacı tarafından geliştirilmiş "Görüşme formu" kullanılmıştır.

\section{Sosyal adalet liderliği ölçeği}

Araştırmada öğretmen algılarına göre, okullardaki sosyal adalet liderliğinin durumunu belirlemek amacıyla "Sosyal Adalet Liderliği Ölçeği (SALÖ)" kullanılmıştır. SALÖ, Özdemir ve Kütküt (2015) tarafından geliştirilmiş 24 maddelik bir ölçektir. Ölçek, destek (12 madde; 1-12 arası), eleştirel bilinç (9 madde; 13-21 arası) ve katılım (3 madde; 22-24 arası) olmak üzere üç boyuttan oluşmaktadır. Ölçekte 5'li Likert tipi derecelendirme kullanılmıştır. Derecelendirme ve aralıkları; "1-Hiç katılmıyorum (1.00-1.79)", "2-Biraz katılıyorum (1.80-2.59)", "3-Orta düzeyde katılıyorum (2.603.39)", "4-Katılıyorum (3.40-4.19)", "5-Kesinlikle katılıyorum (4.20-5.00)" şeklinde puanlanmıştır.

Ölçeğin güvenirliğini test etmek amacıyla; ölçek Likert tipi olduğundan ve tek uygulamadan elde edildiğinden Cronbach Alpha güvenirlik katsayısı $(\alpha)$ hesaplanmıştır. Aşağıdaki tabloda görüldüğü 
üzere güvenirlik katsayısı " $\alpha=.97$ " olarak bulunmuştur. Psikolojik bir test için hesaplanan güvenirlik katsayısının .70 ve daha yüksek olması test puanlarının güvenirliği için genel olarak yeterli görülmektedir (Büyüköztürk, 2013). Sosyal adalet liderliği ölçeği güvenirlik analizine aşağıdaki tabloda yer verilmiştir.

Tablo 2.

Sosyal adalet liderliği ölçeği güvenirlik analizi

\begin{tabular}{rr}
\hline Alfa Katsayısı & Gözlem Sayısı \\
\hline .966 & 24 \\
\hline
\end{tabular}

Sosyal adalet liderliği ölçeğinden elde edilen verilerle aşağıdaki sorulara cevap aranacaktır:

$>$ Öğretmen algılarına göre, okul yöneticilerinin sosyal adalet liderliği ne düzeydedir? Alt sorular:

1. Öğretmen algılarına göre, okul yöneticilerinin sosyal adalet liderliği düzeyi cinsiyet değişkenine göre farklılık göstermekte midir?

2. Öğretmen algılarına göre, okul yöneticilerinin sosyal adalet liderliği düzeyi medeni durum değişkenine göre farklılık göstermekte midir?

3. Öğretmen algılarına göre, okul yöneticilerinin sosyal adalet liderliği düzeyi yaş değişkenine göre farklılık göstermekte midir?

4. Öğretmen algılarına göre, okul yöneticilerinin sosyal adalet liderliği düzeyi öğrenim durumu değişkenine göre farklılık göstermekte midir?

\section{Görüşme formu}

Araştırmada öğretmen görüşlerine göre, okullardaki sosyal adalet liderliğinin durumunu belirlemek amacıyla öncelikle; "Okulda sosyal adaleti sağlama açısından, yöneticinin sahip olması gereken davranışlar nelerdir?" sorusuna cevap aramak amacıyla literatür taraması yapılmıştır. Araştırmanın kapsam geçerliliği; iki eğitim bilimleri uzmanı, iki okul müdürü ve kıdemli iki öğretmen tarafından belirlenmiştir. Ayrıca araştırma sorularının, "sosyal adalet liderliği ölçeği" nde yer alan boyutlarla ilgili bir biçimde olmasına da dikkat edilmiştir. Bunlara bağıı olarak araştırmada kullanılacak olan veri toplama aracı geliştirilmiştir. Araştırmacı tarafından oluşturulan görüşme formu şu sorulardan oluşmaktadır:

Okulda sosyal adaleti sağlama açısından, yöneticinizi bir lider olarak nasıl algılıyorsunuz? Alt sorular:

1. Yöneticiniz okulda gerçekleştirilen çalışmalara ve dezavantajlı kişilere dönük destek sağlar mı?

2. Yöneticinizin farklılıklara yaklaşımı hakkında ne düşünüyorsunuz?

3. Yöneticinizin okuldaki uygulamalarda öğretmen görüşlerine başvurma durumu hakkında ne düşünüyorsunuz?

Bu çalışmada, "görüşme-standartlaştırımış açık uçlu görüşme" tarzı kullanılmıştır. Patton'a göre görüşmenin amacı, bir bireyin iç dünyasına girmek ve onun bakış açısını anlamaktır. Görüşme yoluyla, deneyimler, tutumlar, düşünceler, niyetler, yorumlar ve zihinsel algılar ve tepkiler gibi gözlenemeyen şeyler anlamaya çalışılır. Bu süreçte, sorulan sorulara, karşı tarafın rahat, dürüst ve doğru bir şekilde tepkide bulunmasını sağlamak görüşmecinin görevidir. Patton’a göre görüşme yaklaşımlarından biri de "standartlaştırılmış açık uçlu görüşme tarzı"dır. Patton'a göre bu yaklaşım, "dikkatlice yazılmış ve belirli bir sıraya konmuş bir dizi sorudan oluşur ve her görüşülen bireye bu sorular aynı tarzda ve sırada sorulur". Bu yaklaşım, bazı insanlardan daha yoğun ve çok, bazı insanlardan ise daha az sistematik ve yüzeysel bilgi edinilmesine yol açabilecek olan görüşmeci 
yanlılığını veya öznelliğini azaltır. Standartlaştırılmış açık uçlu görüşme, bir araştırmanın başkaları tarafından tekrar edilmesi olasılığını önemli ölçüde arttırır (Yıldııım ve Şimşek, 2016).

\section{Verilerin toplanması ve analizi}

Bu araştırmanın gerçekleştirilebilmesi için "Etik Kurul Onayı (Hacettepe Üniversitesi Rektörlük Makamının 14.07.2020 tarihli ve 35853172-600/00001156231 sayılı yazısı)" alınmıştır; bu araştırma, Hacettepe Üniversitesi Senatosu Etik Komisyonunun 23 Haziran 2020 tarihinde yapmış olduğu toplantıda incelenmiş olup, etik açıdan uygun bulunmuştur. Araştırmada kullanılan ölçme aracı, Özdemir ve Kütküt (2015)' ten alınan ölçek kullanım izni ve Ankara İl Millî Eğitim Müdürlügü̈nden alınan yasal izin belgesi ile örneklem kapsamındaki okullara gidilerek, 2019-2020 eğitim öğretim yılı 27-31 Ağustos 2020 tarihleri arasında (sene başı öğretmen seminer döneminde) uygulanmıştır. Uygulamalar; araştırmacı tarafından, okul yönetimi ve öğretmenlerin gönüllülüğü dikkate alınarak, örneklem listesi doğrultusunda her bir okulda uygulamaya katılan öğretmenlerle görüşülerek, ölçme aracı hakkında bilgi verilmesi ile birlikte gerçekleştirilmiştir. Görüşmeler, yüz yüze 15-30 dakika arasında gerçekleştirilmiştir. Iki farklı kaynaktan toplanan nicel ve nitel veri setleri birbirinden bağımsız toplanmıştır. Verilerin analizi doğrultusunda; nicel ve nitel veriler ayrı ayrı analiz edilmiştir.

\section{Nicel verilerin analizi}

Büyük gruplar üzerinden toplanan verilerin, normal dağılıma yakın dağılım gösterdikleri kabul edilir ve buna göre parametrik istatistikler seçilebilir. Dağılımın normal dağılımdan aşırı sapma göstermediği şeklinde bir varsayımı ileri sürmek için öngörülen örneklem büyüklüğü genellikle 30 ve daha büyük olarak gösterilmektedir. Ancak sosyal bilimlerde pek çok araştırmalar, özellikle de deneysel araştırmalar, daha küçük gruplar üzerinde yapılmaktadır. Literatürde, alt grupların her birinin büyüklüklerinin 15 ve daha yüksek olması durumunda parametrik bir istatistiğin kullanılmasının, analizde hesaplanacak " $p$ " anlamlılık düzeyinde önemli bir sapmaya yol açmadığına ilişkin incelemelere rastlanmaktadır (Büyüköztürk, 2013). Bu kapsamda verilerin çözümlenmesi doğrultusunda, öncelikle frekans ve yüzde analizleri yapılmıştır. Ayrıca iki alt kategorili değişkenlerde, bağımsız (ilişkisiz) örneklemler için t-testi; üç ya da daha fazla alt kategorili değişkenlerde ise, tek yönlü varyans analizi (ANOVA) uygulanmıştır. Bulguların yorumlanmasında, anlamlılık değeri $p<.05$ olarak kabul edilmiştir.

\section{Nitel verilerin analizi}

Görüşme tekniği kullanılarak verilere ulaşılmış bu araştırmada verilerin çözümlenmesinde içerik analizi ve betimsel analiz tekniği kullanılmış, bulgular uygun görülen ve gerekli olan yerlerde nicelleştirilerek (sayı kullanılarak) sunulmuştur. Nitel bulgular analize açıklık getirmek, güvenirliği arttırmak için nicel ifadeler kullanılarak belirtilebilir. Betimsel analizde, elde edilen veriler daha önceden belirlenen temalara göre özetlenir ve yorumlanır. Bu yaklaşım göre, veriler araştırma sorularının ortaya koyduğu temalara göre düzenlenebileceği gibi, görüşme ve gözlem süreçlerinde kullanılan sorular ya da boyutlar dikkate alınarak da sunulabilir. İçerik analizinde ise temel amaç, toplanan verileri açıklayabilecek kavramlara ve ilişkilere ulaşmaktır. Betimsel analizde özetlenen ve yorumlana veriler, içerik analizinde daha derin bir işleme tabi tutulur ve betimsel bir yaklaşımla fark edilemeyen kavram ve temalar bu analiz sonucu keşfedilebilir. Araştırmacı, araştırma problemi ile ilgili alanyazını tarayarak bu ketegorileri oluşturabilir ya da bu tema veya kategoriler verinin analizi sırasında araştırmacı tarafından oluşturulabilir (Yıldırım ve Şimşek, 2016). Bu araştırmada, araştırma problemi ile ilgili alanyazın taranarak ketegoriler/temalar oluşturulmuştur; bunlar "genel, destek, eleştirel bilinç ve katılım" kategorileridir. 
Nitel araştırma yöntemlerinde geçerlik kavramı araştırmacının araştırdığı olguyu, olduğu haliyle ve olabildiğince tarafsız gözlemesi anlamına gelmektedir. Toplanan verilerin ayrıntılı olarak rapor edilmesi ve araştırmacının sonuçlara nasıl ulaştı̆̆ını açıklaması nitel bir araştırmada geçerliğin önemli ölçütleri arasında yer almaktadır. iç̧ geçerliği/inandırıcılığı sağlama konusunda araştırmacılardan hem veri toplama süreçlerinde hem de verilerin analizi ve yorumlanması süreçlerinde tutarlı olması ve bu tutarlılı̆ın nasıl sağlandığı konusunda açıklama yapması beklenmektedir. Betimsel türden bir analizin kullanıldığı bir araştırmada, görüşülen bireylerden doğrudan alıntılara yer vermek ve bunlardan yola çıkarak sonuçları açıklamak geçerlik için önemli olmaktadır (Yıldırım ve Şimşek, 2016). Katılımcıların görüşleri incelenirken kullandıkları sözcük, cümle ve kavramlardan yola çıkılarak özellikle kendi ifadelerinde yer verdikleri kavramların kullanılmasına özen gösterilmiştir. Araştırmada inandırıcılı̆̆ı sağlamak ve öğretmen görüşlerini daha açık bir biçimde yansıtabilmek amacıyla doğrudan alıntılara da yer verilmiştir. Katılımcıların görüşlerinden elde edilen verilerin analizinde araştırmanın başlangı ında belirlenmiş olan kategorilere uygun birtakım alt kategoriler oluşturulmuş ve bu alt kategoriler araştırmanın amacına hizmet edecek bir şekilde benzerlik ve farklııklarına göre gruplandırılmıştır. Bu gruplama sonucunda araştırmaya katılan öğretmen görüşleri arasındaki benzerlikler ve farklılıklar belirlenmeye çalışılmıştır. Sonrasında ise, ortaya çıkan bulgular yorumlanarak sorunlar incelenmiştir. Ayrıca, katılımcıların gerçek ismi yerine takma isimler kullanılmıştır.

\section{Bulgular}

Bu bölümde; verilere ve veri analizine dayalı olarak bulgulara yer verilmiştir. Bu bölüm; sosyal adalet liderliği ölçeğinden elde edilen bulgular, görüşme sonucu elde edilen bulgular ile nicel ve nitel bulguların birleştirilmesi olmak üzere üç ayrı başlık biçiminde ele alınmıştır.

\section{Sosyal adalet liderliği ölçeğinden elde edilen bulgular}

Araştırmada ilk olarak; öğretmen algılarına göre, okul yöneticilerinin sosyal adalet liderliği düzeyi incelenmiştir. Aşağıdaki tabloda, okul yöneticilerinin sosyal adalet liderliği düzeyine ilişkin betimsel istatistiklere yer verilmiştir.

Tablo 3.

Okul yöneticilerinin sosyal adalet liderliği düzeyine ilişkin betimsel istatistikler

\begin{tabular}{lrrr}
\hline Boyutlar & $\mathbf{n}$ & $\overline{\mathbf{x}}$ & $\mathbf{S S}$ \\
\hline Destek & 436 & 4.03 & .61 \\
Eleştirel bilinç & 436 & 3.88 & .85 \\
Katılım & 436 & 3.92 & .92 \\
Sosyal adalet liderliği & 436 & 3.96 & .69 \\
(Genel) & & & \\
\hline
\end{tabular}

Makalenin Tablo incelendiğinde; öğretmenlerin okul yöneticilerinin sosyal adalet liderliği düzeyine ilişkin algılarının katılıyorum düzeyinde $(\bar{x}=3.96)$ olduğu görülmektedir. Ayrıca destek $(\bar{x}=$ 4.03), eleştirel bilinç ( $\bar{x}=3.88$ ) ve katılım ( $\bar{x}=3.92)$ boyutlarında da öğretmenlerin okul yöneticilerinin sosyal adalet liderliği düzeyine ilişkin algılarının katılıyorum düzeyinde olduğu görülmektedir. Boyutlar incelendiğinde, öğretmenlerin okul yöneticilerinin sosyal adalet liderliği düzeyini en yüksek algıladıkları boyut, destek; en düşük algıladıkları boyut ise, eleştirel bilinç olmuştur.

Cinsiyet değişkenine göre, okul yöneticilerinin sosyal adalet liderliği düzeyine ilişkin t-testi sonuçlarına aşağıdaki tabloda yer verilmiştir. 
Tablo 4.

Cinsiyet değişkenine göre okul yöneticilerinin sosyal adalet liderliği düzeyine ilişkin t-testi sonuçları

\begin{tabular}{llllllll}
\hline Boyutlar & Cinsiyet & $\mathbf{n}$ & $\overline{\mathbf{x}}$ & $\mathbf{S S}$ & $\mathbf{s d}$ & $\mathbf{t}$ & $\mathbf{p}$ \\
\hline Destek & Kadın & 320 & 3.99 & .60 & 434 & 2.73 & $.00^{*}$ \\
& Erkek & 116 & 4.17 & .60 & & & $.00^{*}$ \\
\hline Eleştirel bilinç & Kadın & 320 & 3.77 & .88 & 434 & 4.60 & .15 \\
& Erkek & 116 & 4.19 & .67 & & & \\
\hline Katılım & Kadın & 320 & 3.89 & .90 & 434 & 1.42 & $.00^{*}$ \\
& Erkek & 116 & 4.03 & .96 & & & 3.55 \\
\hline Sosyal adalet & Kadın & 320 & 3.89 & .70 & 434 & & \\
liderliği (Genel) & Erkek & 116 & 4.16 & .64 & & &
\end{tabular}

Tablo incelendiğinde; öğretmenlerin okul yöneticilerinin sosyal adalet liderliği düzeyine ilişkin algıları, cinsiyet değişkenine göre anlamlı bir farklılık göstermektedir, $t(434)=2.73, p<.05$. Erkek öğretmenlerin okul yöneticilerinin sosyal adalet liderliği düzeyine ilişkin algıları ( $\bar{x}=4.16$-katılıyorum düzeyinde), kadın öğretmenlere ( $\bar{x}=3.89$-katılıyorum düzeyinde) göre daha yüksektir. Araştırma bulgusu, okul yöneticilerinin sosyal adalet liderliği düzeyi ile cinsiyet arasında anlamlı bir ilişkinin olduğu şeklinde de yorumlanabilir.

Katılım boyutu dışındaki diğer boyutlarda; öğretmenlerin okul yöneticilerinin sosyal adalet liderliği düzeyine ilişkin algıları, cinsiyet değişkenine göre anlamlı bir farklılık göstermektedir. Destek boyutu, $t(434)=2.73, p<.05$; eleştirel bilinç boyutu, $t(434)=4.60, p<.05$. Katılım boyutunda ise öğretmenlerin okul yöneticilerinin sosyal adalet liderliği düzeyine ilişkin algıları, cinsiyet değişkenine göre anlamlı bir farklılık göstermemektedir, $t(434)=1.42, p>.05$. Erkek öğretmenlerin destek boyutuna ilişkin algıları ( $\bar{x}=4.17$-katılıyorum düzeyinde), kadın öğretmenlere ( $\bar{x}=3.99$-katılıyorum düzeyinde) göre daha yüksektir; erkek öğretmenlerin eleştirel bilinç boyutuna ilişkin algıları $(\bar{x}=4.19$ katılıyorum düzeyinde), kadın öğretmenlere ( $\bar{x}=3.77$-katılıyorum düzeyinde) göre daha yüksektir.

Medeni durum değişkenine göre, okul yöneticilerinin sosyal adalet liderliği düzeyine ilişkin ttesti sonuçlarına aşağıdaki tabloda yer verilmiştir.

Tablo 5 .

Medeni durum değişkenine göre okul yöneticilerinin sosyal adalet liderliği düzeyine ilişkin t-testi sonuçları

\begin{tabular}{|c|c|c|c|c|c|c|c|}
\hline Boyutlar & $\begin{array}{l}\text { Medeni } \\
\text { Durum }\end{array}$ & $\mathrm{n}$ & $\overline{\mathbf{x}}$ & SS & sd & $\mathbf{t}$ & $\mathbf{p}$ \\
\hline \multirow[t]{2}{*}{ Destek } & Evli & 396 & 4.06 & .60 & 434 & 3.07 & $.00^{*}$ \\
\hline & Bekâr & 40 & 3.75 & .64 & & & \\
\hline \multirow[t]{2}{*}{ Eleştirel bilinç } & Evli & 396 & 3.89 & .88 & 434 & .57 & .56 \\
\hline & Bekâr & 40 & 3.81 & .51 & & & \\
\hline \multirow[t]{2}{*}{ Katılım } & Evli & 396 & 3.97 & .91 & 434 & 3.36 & $.00^{*}$ \\
\hline & Bekâr & 40 & 3.46 & .88 & & & \\
\hline \multirow{2}{*}{$\begin{array}{l}\text { Sosyal adalet } \\
\text { liderliği (Genel) }\end{array}$} & Evli & 396 & 3.99 & .70 & 434 & 2.16 & $.03^{*}$ \\
\hline & Bekâr & 40 & 3.74 & .57 & & & \\
\hline
\end{tabular}

$p<.05$

Tablo incelendiğinde; öğretmenlerin okul yöneticilerinin sosyal adalet liderliği düzeyine ilişkin algıları, medeni durum değişkenine göre anlamlı bir farklılık göstermektedir, t $(434)=2.16, p<.05$. Evli 


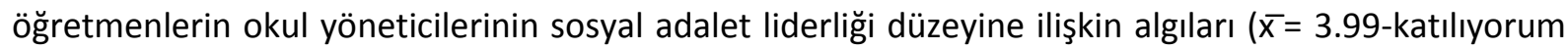

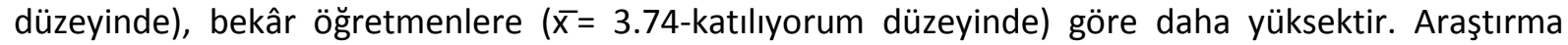
bulgusu, okul yöneticilerinin sosyal adalet liderliği düzeyi ile medeni durum arasında anlamlı bir ilişkinin olduğu şeklinde de yorumlanabilir.

Eleştirel bilinç boyutu dışındaki diğer boyutlarda; öğretmenlerin okul yöneticilerinin sosyal adalet liderliği düzeyine ilişkin algıları, medeni durum değişkenine göre anlamlı bir farklılık göstermektedir. Destek boyutu, t (434)= 3.07, $p<.05$; katılım boyutu, $t(434)=3.36, p<.05$. Eleştirel bilinç boyutunda ise öğretmenlerin okul yöneticilerinin sosyal adalet liderliği düzeyine ilişkin algıları, medeni durum değişkenine göre anlamlı bir farklılık göstermemektedir, $t(434)=.57, p>.05$. Evli öğretmenlerin destek boyutuna ilişkin algıları ( $\bar{x}=4.06$-katılıyorum düzeyinde), bekâr öğretmenlere $(\bar{x}=3.75$-katılıyorum düzeyinde); evli öğretmenlerin katılım boyutuna ilişkin algıları $(\bar{x}=3.97-$ katılıyorum düzeyinde), bekâr öğretmenlere ( $\bar{x}=3.46$-katılıyorum düzeyinde) göre daha yüksektir.

Yaş değişkenine göre, okul yöneticilerinin sosyal adalet liderliği düzeyine ilişkin tek yönlü varyans analizi (ANOVA) sonuçlarına aşă̆ıdaki tabloda yer verilmiştir.

Tablo 6.

Yaş değişkenine göre okul yöneticilerinin sosyal adalet liderliği düzeyine ilişkin tek yönlü varyans analizi (anova) sonuçları

\begin{tabular}{|c|c|c|c|c|c|c|c|}
\hline Boyutlar & Yaş & $\mathrm{n}$ & $\overline{\mathbf{x}}$ & SS & $\mathbf{F}$ & $\mathbf{p}$ & Anlamlı Fark \\
\hline \multirow[t]{4}{*}{ Destek } & $21-30$ & 16 & 4.56 & .34 & 14.647 & $.00^{*}$ & \multirow{4}{*}{$\begin{array}{c}21-30 / 31-40, \quad 21- \\
30 / 41-50, \quad 41- \\
50 / 31-40, \quad 51 \text { ve } \\
\text { üzeri/31-40 }\end{array}$} \\
\hline & $31-40$ & 228 & 3.87 & .53 & & & \\
\hline & $41-50$ & 148 & 4.18 & .64 & & & \\
\hline & 51 ve üzeri & 44 & 4.21 & .67 & & & \\
\hline \multirow[t]{4}{*}{ Eleştirel bilinç } & $21-30$ & 16 & 4.22 & .18 & \multirow[t]{4}{*}{10.731} & \multirow[t]{4}{*}{$.00^{*}$} & \multirow{4}{*}{$\begin{array}{r}21-30 / 31-40,41- \\
50 / 31-40, \quad 51 \text { ve } \\
\text { üzeri/31-40 }\end{array}$} \\
\hline & $31-40$ & 228 & 3.67 & .81 & & & \\
\hline & $41-50$ & 148 & 4.12 & .86 & & & \\
\hline & 51 ve üzeri & 44 & 4.08 & .93 & & & \\
\hline \multirow[t]{4}{*}{ Katılım } & $21-30$ & 16 & 4.00 & .00 & \multirow[t]{4}{*}{5.990} & \multirow[t]{4}{*}{$.00^{*}$} & \multirow{4}{*}{$\begin{array}{r}21-30 / 31-40,41- \\
50 / 31-40\end{array}$} \\
\hline & $31-40$ & 228 & 3.76 & .98 & & & \\
\hline & $41-50$ & 148 & 4.16 & .79 & & & \\
\hline & 51 ve üzeri & 44 & 4.00 & .99 & & & \\
\hline \multirow{4}{*}{$\begin{array}{l}\text { Sosyal adalet } \\
\text { liderliği (Genel) }\end{array}$} & $21-30$ & 16 & 4.36 & .22 & \multirow[t]{4}{*}{12.525} & \multirow[t]{4}{*}{$.00^{*}$} & \multirow{4}{*}{$\begin{array}{r}21-30 / 31-40, \quad 41- \\
50 / 31-40, \quad 51 \text { ve } \\
\text { üzeri/31-40 }\end{array}$} \\
\hline & $31-40$ & 228 & 3.78 & .63 & & & \\
\hline & $41-50$ & 148 & 4.15 & .70 & & & \\
\hline & 51 ve üzeri & 44 & 4.14 & .79 & & & \\
\hline
\end{tabular}

${ }^{*} p<.05$

Tablodaki analiz sonuçları; öğretmenlerin okul yöneticilerinin sosyal adalet liderliği düzeyine ilişkin algıları arasında yaş değişkenine göre anlamlı bir fark olduğunu göstermektedir, $F=12.525, p<$ .05. Başka bir deyişle, öğretmenlerin okul yöneticilerinin sosyal adalet liderliği düzeyine ilişkin algıları, yaş değişkenine bağlı olarak anlamlı bir şekilde değişmektedir. Yaş grupları arası farkların hangi gruplar arasında olduğunu bulmak amacıyla yapılan Dunnets's $C$ testinin sonuçlarına göre; 21-30 yaş ( $\bar{x}=4.36$-kesinlikle katılıyorum düzeyinde), $41-50$ yaş ( $\bar{x}=4.15$-katılıyorum düzeyinde) ile 51 ve üzeri

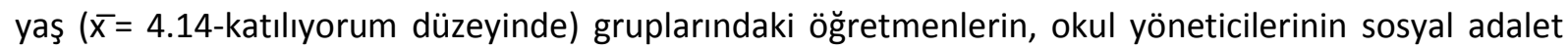
liderliği düzeyine ilişkin algılarının $31-40$ yaş $(\bar{x}=3.78$-katılıyorum düzeyinde) grubundaki öğretmenlerden daha yüksek olduğu belirlenmiştir. 
Analiz sonuçları; öğretmenlerin destek boyutuna ilişkin algıları arasında yaş değişkenine göre anlamlı bir fark olduğunu göstermektedir, $F=14.647, p<.05$. Başka bir deyişle, öğretmenlerin destek boyutuna ilişkin algıları, yaş değişkenine bağlı olarak anlamlı bir şekilde değişmektedir. Yaş grupları arası farkların hangi gruplar arasında olduğunu bulmak amacıyla yapılan Dunnets's $\mathrm{C}$ testinin sonuçlarına göre; $21-30$ yaş $(\bar{x}=4.56$-kesinlikle katılıyorum düzeyinde), $41-50$ yaş $(\bar{x}=4.18$ katılıyorum düzeyinde) ile 51 ve üzeri yaş ( $\bar{x}=4.21$-kesinlikle katılıyorum düzeyinde) gruplarındaki öğretmenlerin, destek boyutuna ilişkin algılarının $31-40$ yaş $(\bar{x}=3.87$-katılıyorum düzeyinde) grubundaki öğretmenlerden daha yüksek olduğu belirlenmiştir. Ayrıca $21-30$ yaş $(\bar{x}=4.56-k e s i n l i k l e$ katılıyorum düzeyinde) grubundaki öğretmenlerin, destek boyutuna ilişkin algılarının 41-50 yaş ( $\bar{x}=$ 4.18-katılıyorum düzeyinde) grubundaki öğretmenlerden daha yüksek olduğu belirlenmiştir.

Analiz sonuçları; öğretmenlerin eleştirel bilinç boyutuna ilişkin algıları arasında yaş değişkenine göre anlamlı bir fark olduğunu göstermektedir, 10.731, $p<.05$. Başka bir deyişle, öğretmenlerin eleştirel bilinç boyutuna ilişkin algıları, yaş değişkenine bağlı olarak anlamlı bir şekilde değişmektedir. Yaş grupları arası farkların hangi gruplar arasında olduğunu bulmak amacıyla yapılan Dunnets's $C$ testinin sonuçlarına göre; $21-30$ yaş ( $\bar{x}=4.22-$ kesinlikle katılıyorum düzeyinde), $41-50$ yaş ( $\bar{x}=4.12$-katılıyorum düzeyinde) ile 51 ve üzeri yaş $(\bar{x}=4.08$-katılıyorum düzeyinde) gruplarındaki

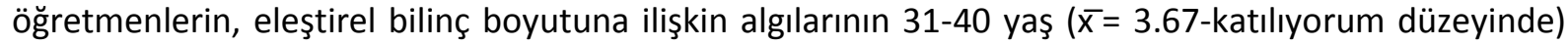
grubundaki öğretmenlerden daha yüksek olduğu belirlenmiştir.

Analiz sonuçları; öğretmenlerin katılım boyutuna ilişkin algıları arasında yaş değişkenine göre anlamlı bir fark olduğunu göstermektedir, $F=5.990, p<.05$. Başka bir deyişle, öğretmenlerin katılım boyutuna ilişkin algıları, yaş değişkenine bağlı olarak anlamlı bir şekilde değişmektedir. Yaş grupları arası farkların hangi gruplar arasında olduğunu bulmak amacıyla yapılan Dunnets's $C$ testinin sonuçlarına göre; $21-30$ yaş $(\bar{x}=4.00$-katılıyorum düzeyinde) ve $41-50$ yaş $(\bar{x}=4.16$-katılıyorum düzeyinde) gruplarındaki öğretmenlerin, katılım boyutuna ilişkin algılarının $31-40$ yaş $(\bar{x}=3.76-$ katılıyorum düzeyinde) grubundaki öğretmenlerden daha yüksek olduğu belirlenmiştir.

Öğrenim durumu değişkenine göre, okul yöneticilerinin sosyal adalet liderliği düzeyine ilişkin t-testi sonuçlarına aşağıdaki tabloda yer verilmiştir.

Tablo 7.

Öğrenim durumu değişkenine göre okul yöneticilerinin sosyal adalet liderliği düzeyine ilişkin t-testi sonuçları

\begin{tabular}{|c|c|c|c|c|c|c|c|}
\hline Boyutlar & $\begin{array}{l}\text { Öğrenim } \\
\text { Durumu }\end{array}$ & $n$ & & SS & sd & $t$ & $p$ \\
\hline \multirow[t]{2}{*}{ Destek } & Lisans & 400 & 4.05 & .61 & 434 & 1.35 & .17 \\
\hline & Lisansüstü & 36 & 3.90 & .63 & & & \\
\hline \multirow[t]{2}{*}{ Eleştirel bilinç } & Lisans & 400 & 3.88 & .88 & 434 & .24 & .81 \\
\hline & Lisansüstü & 36 & 3.85 & .52 & & & \\
\hline \multirow[t]{2}{*}{ Katılım } & Lisans & 400 & 3.96 & .87 & 434 & 2.55 & $.01^{*}$ \\
\hline & Lisansüstü & 36 & 3.55 & 1.30 & & & \\
\hline \multirow{2}{*}{$\begin{array}{l}\text { Sosyal adalet } \\
\text { liderliği (Genel) }\end{array}$} & Lisans & 400 & 3.97 & .70 & 434 & 1.12 & .26 \\
\hline & Lisansüstü & 36 & 3.84 & .62 & & & \\
\hline
\end{tabular}

${ }^{*} p<.05$

Tablo incelendiğinde; öğretmenlerin okul yöneticilerinin sosyal adalet liderliği düzeyine ilişkin algıları, öğrenim durumu değişkenine göre anlamlı bir farklılık göstermektedir, $t(434)=1.12, p<.05$. Lisans mezunu öğretmenlerin okul yöneticilerinin sosyal adalet liderliği düzeyine ilişkin algıları $(\bar{x}=$ 3.97-katılıyorum düzeyinde), lisansüstü mezunu öğretmenlere ( $\bar{x}=3.84$-katılıyorum düzeyinde) göre 
daha yüksektir. Araştırma bulgusu, okul yöneticilerinin sosyal adalet liderliği düzeyi ile öğrenim durumu arasında anlamlı bir ilişkinin olduğu şeklinde de yorumlanabilir.

Katılım boyutu dışındaki diğer boyutlarda; öğretmenlerin okul yöneticilerinin sosyal adalet liderliği düzeyine ilişkin algıları, öğrenim durumu değişkenine göre anlamlı bir farklılık göstermemektedir. Destek boyutu, t $(434)=1.35, \mathrm{p}>.05$; eleştirel bilinç boyutu, $t(434)=.24, \mathrm{p}>.05$. Katılım boyutunda ise öğretmenlerin okul yöneticilerinin sosyal adalet liderliği düzeyine ilişkin algıları, öğrenim durumu değişkenine göre anlamlı bir farklılık göstermektedir, t $(434)=2.55, p<.05$. Lisans mezunu öğretmenlerin katılım boyutuna ilişkin algıları $(\bar{x}=3.96$-katılıyorum düzeyinde), lisansüstü mezunu öğretmenlere ( $\bar{x}=3.55$-katılıyorum düzeyinde) göre daha yüksektir.

\section{Görüşme sonucu elde edilen bulgular}

Araştırma problemi ile ilgili alanyazın taranarak oluşturulan kategoriler şunlardır; genel, destek, eleştirel bilinç ve katılım. Ayrıca öğretmen görüşleri kavramsal bağlamda analiz edilerek alt kategoriler oluşturulmuştur. Okul yöneticilerinin sosyal adalet liderliğinin durumuna ilişkin görüşme sonucuna göre kategorilendirmeye aşağıdaki tabloda yer verilmiştir.

Tablo 8.

Okul yöneticilerinin sosyal adalet liderliğinin durumuna ilişkin görüşme sonucuna göre kategorilendirme

\begin{tabular}{|c|c|c|}
\hline Kişi sayısı & Kategori-alt kategori & Görüş (doğrudan alıntı örneği) \\
\hline 8 & Genel-Sosyal adalet & $\begin{array}{l}\text { Her zaman adaletli olmaya çalışan ve elinden } \\
\text { geldiğince de bunu yapan bir yöneticidir. }\end{array}$ \\
\hline 3 & Genel-Eşitlik & $\begin{array}{r}\text { Eşit davranmaya çalışıyor. Belirli kuralları herkes } \\
\text { için uyguluyor. }\end{array}$ \\
\hline 3 & Genel-Subjektif davranış & $\begin{array}{r}\text { Biraz kişiye göre hareket ettiklerini gözlemliyorum. } \\
\text { Tam bir adalet üzerine hareket etmediklerini bazen } \\
\text { görüyorum. }\end{array}$ \\
\hline 17 & Destek-Olumlu destek & Destek sağlar, çoğu zaman bizi yüreklendirir. \\
\hline 2 & Destek-Olumsuz destek & $\begin{array}{r}\text { Olumsuz yönde sağlar. Okulun WhatsApp grubunda } \\
\text { üstü kapalı ifşa eder. Ayrıca konusu başka olan bir } \\
\text { konu belirleyerek öğretmenleri toplantıya çağırıp } \\
\text { söz konusu arkadaşı herkese anlatır. Sonrasında ne } \\
\text { kadar anlayışlı olduğunu bu yaşananlardan hiç } \\
\text { haberi olmadığını bildirir. }\end{array}$ \\
\hline 19 & Eleştirel bilinç-Farklılıklara açık/saygılı & $\begin{array}{r}\text { Farklılıklara saygılı ve eşit yaklaşım sergilendiğini } \\
\text { düşünüyorum. }\end{array}$ \\
\hline 1 & Eleştirel bilinç-Farklılıklara kapalı & Kesinlikle yeni fikir ve görüşlere kapalıdır. \\
\hline 17 & Katılım-Katılımcı yönetim & $\begin{array}{l}\text { Her uygulamada öğretmenlere mutlaka danışır ve } \\
\text { kararları bu doğrultuda verir. }\end{array}$ \\
\hline 3 & Katılım-Katılımcı olmayan yönetim & $\begin{array}{l}\text { Bunu sadece kendi fikrini dayatmak için yapar. } \\
\text { Sonunda mutlaka müdürün dediği olur. }\end{array}$ \\
\hline
\end{tabular}

Tablo incelendiğinde; "genel" kategorisi altında sosyal adalete vurgu yapan kişi sayısının (8) çoğunlukta olduğu görülmektedir. Eşitlik ve subjektif davranışa vurgu yapan kişi sayısı (3'er) ise daha azdır. "Her zaman adaletli olmaya çalışan ve elinden geldiğince de bunu yapan bir yöneticidir" görüşü okul yöneticilerinin sosyal adaleti sağladığına işarettir. "Eşit davranmaya çalışıyor. Belirli kuralları herkes için uyguluyor" görüşü okul yöneticilerinin eğitim paydaşları arasında eşitliğe önem verdiğini göstermektedir. "Biraz kişiye göre hareket ettiklerini gözlemliyorum. Tam bir adalet üzerine hareket 
etmediklerini bazen görüyorum" görüşü ise okul yöneticilerinin uygulamalarda kişiye göre davranış sergilediklerine ve tarafsız olmadıklarına işaret etmektedir.

"Destek" kategorisi altında olumlu desteğe vurgu yapan kişi sayısının (17) çoğunlukta olduğu görülmektedir. Olumsuz desteğe vurgu yapan kişi sayısı (2) ise azdır. "Destek sağlar, çoğu zaman bizi yüreklendirir" görüşü okul yöneticilerinin personeli destekleyici bir yapıda olduklarını göstermektedir. "Olumsuz yönde sağlar. Okulun WhatsApp grubunda üstü kapalı ifşa eder. Ayrıca konusu başka olan bir konu belirleyerek öğretmenleri toplantıya çağırıp söz konusu arkadaşı herkese anlatır. Sonrasında ne kadar anlayışı olduğunu bu yaşananlardan hiç haberi olmadığını bildirir" görüşü ise okul yöneticilerinin destekleyici olmadıklarına işaret etmektedir.

"Eleştirel bilinç" kategorisi altında farklılıklara açık/saygılı olmaya vurgu yapan kişi sayısının (19) çoğunlukta olduğu görülmektedir. Farklılıklara kapalı olmaya vurgu yapan kişi sayısı (1) ise azdır. "Farklılıklara saygılı ve eşit yaklaşım sergilendiğini düşünüyorum" görüşü okul yöneticilerinin farklııklara karşı açık, saygılı ve eşit yaklaştıklarını göstermektedir. "Kesinlikle yeni fikir ve görüşlere kapalıdır" görüşü ise okul yöneticilerinin farklılıklara ve yeni görüşlere karşı kapalı olduklarına işaret etmektedir.

"Katılım" kategorisi altında olumlu katılımcı yönetim anlayışına vurgu yapan kişi sayısının (17) çoğunlukta olduğu görülmektedir. Katılımcı olmayan yönetim anlayışına vurgu yapan kişi sayısı (3) ise azdır. "Her uygulamada öğretmenlere mutlaka danışır ve kararları bu doğrultuda verir" görüşü okul yöneticilerinin öğretmen görüşlerine ve katılımına önem verdiklerini göstermektedir. "Bunu sadece kendi fikrini dayatmak için yapar. Sonunda mutlaka müdürün dediği olur" görüşü ise okul yöneticilerinin katılımcılığa önem vermeyip sadece kendi fikirleri doğrultusunda hareket ettiklerine işaret etmektedir.

Okul yöneticilerinin sosyal adalet liderliğinin durumuna ilişkin görüşme sonucuna göre kategorilendirmeye ilişkin sayısal verilere aşağıdaki tabloda yer verilmiştir.

Tablo 9.

Kategorilendirmeye ilişkin sayısal veriler

\begin{tabular}{|c|c|c|c|c|c|c|c|c|c|c|c|c|}
\hline \multirow{2}{*}{$\begin{array}{l}\text { Öğretmen görüşü } \\
\text { (Alt kategoriler) } \\
\text { Genel }\end{array}$} & \multirow[b]{2}{*}{1} & \multirow[b]{2}{*}{2} & \multirow[b]{2}{*}{3} & \multirow[b]{2}{*}{4} & \multirow[b]{2}{*}{---} & \multirow[b]{2}{*}{16} & \multirow[b]{2}{*}{17} & \multicolumn{3}{|c|}{ Katılımcılar } & \multirow[t]{2}{*}{ Toplam } & \multirow[t]{2}{*}{$\%$} \\
\hline & & & & & & & & 18 & 19 & 20 & & \\
\hline Sosyal adalet & 1 & & & 1 & --- & & & 1 & & 1 & 8 & 40 \\
\hline Eşitlik & & & & & --- & & & & 1 & & 3 & 15 \\
\hline Subjektif davranış & & & & & --- & & & 1 & & & 3 & 15 \\
\hline Destek & 1 & 2 & 3 & 4 & --- & 16 & 17 & 18 & 19 & 20 & & \\
\hline Olumlu destek & 1 & 1 & 1 & 1 & --- & 1 & 1 & 1 & 1 & & 17 & 85 \\
\hline Olumsuz destek & & & & & --- & & & & & 1 & 2 & 10 \\
\hline Eleştirel bilinç & 1 & 2 & 3 & 4 & --- & 16 & 17 & 18 & 19 & 20 & & \\
\hline Farklılıklara açık/saygılı & 1 & 1 & 1 & 1 & --- & 1 & 1 & 1 & 1 & & 19 & 95 \\
\hline Farklılıklara kapalı & & & & & --- & & & & & 1 & 1 & 5 \\
\hline Katılım & 1 & 2 & 3 & 4 & --- & 16 & 17 & 18 & 19 & 20 & & \\
\hline Katılımcı yönetim & 1 & 1 & 1 & 1 & --- & 1 & 1 & 1 & & & 17 & 85 \\
\hline Katılımcı olmayan yönetim & & & & & --- & & & & 1 & 1 & 3 & 15 \\
\hline
\end{tabular}


Tablo incelendiğinde; "genel" kategorisi altında sosyal adalete vurgu yapan kişi sayısının oran olarak \%40 şeklinde çoğunlukta olduğu görülmektedir. Eşitlik ve subjektif davranışa vurgu yapan kişi sayısının ise oran olarak \%15'er şeklinde daha az olduğu görülmektedir.

"Destek" kategorisi altında olumlu desteğe vurgu yapan kişi sayısının oran olarak \%85 şeklinde görülmektedir. Olumsuz desteğe vurgu yapan kişi sayısının ise oran olarak \%10 şeklinde az olduğu görülmektedir.

"Eleştirel bilinç" kategorisi altında farklılıklara açık/saygılı olmaya vurgu yapan kişi sayısının oran olarak \%95 şeklinde görülmektedir. Farklılıklara kapalı olmaya vurgu yapan kişi sayısının ise oran olarak \%5 şeklinde az olduğu görülmektedir.

"Katılım" kategorisi altında olumlu katılımcı yönetim anlayışına vurgu yapan kişi sayısının oran olarak \%85 şeklinde görülmektedir. Katılımcı olmayan yönetim anlayışına vurgu yapan kişi sayısının ise oran olarak \%15 şeklinde az olduğu görülmektedir.

\section{Nicel ve nitel bulguların birleştirilmesi}

Bu bölümde; öğretmenlerin okul yöneticilerinin sosyal adalet liderliği düzeyine/durumuna ilişkin görüşlerinin ve cevaplarının birbirleriyle birleştirilmesi yoluyla uyuşma durumları incelenmiştir. Öğretmenlerin okul yöneticilerinin sosyal adalet liderliği düzeyine ilişkin algılarının katılıyorum düzeyinde olduğu görülmüştür. Ayrıca öğretmenlerin okul yöneticilerinin sosyal adalet liderliği durumuna ilişkin çoğunlukla sosyal adaleti sağladıklarına dönük olarak cevapları söz konusudur. Bu iki bulgu (nicel ve nitel) birlikte, okullarda sosyal adaletin sağlanması yönünden bir liderliğin varlığına işaret etmektedir ve bulgular birbirini destekler niteliktedir.

Destek boyutunda ele alındığında öğretmenlerin okul yöneticilerinin destek düzeyine ilişkin algılarının katılıyorum düzeyinde olduğu görülmüştür. Ayrıca öğretmenlerin okul yöneticilerinin destek durumuna ilişkin çoğunlukla olumlu yönde bir destek sağladıklarına dönük olarak cevapları söz konusudur. Bu iki bulgu (nicel ve nitel) birlikte, okullarda desteğin sağlanması yönünden bir sosyal adalet liderliğinin varlığına işaret etmektedir ve bulgular birbirini destekler niteliktedir.

Eleştirel bilinç boyutunda ele alındığında öğretmenlerin okul yöneticilerinin destek düzeyine ilişkin algılarının katılıyorum düzeyinde olduğu görülmüştür. Ayrıca öğretmenlerin okul yöneticilerinin eleştirel bilinç durumuna ilişkin çoğunlukla olumlu yönde bir destek sağladıklarına dönük olarak cevapları söz konusudur. Bu iki bulgu (nicel ve nitel) birlikte, okullarda eleştirel bilincin sağlanması yönünden bir sosyal adalet liderliğinin varlığına işaret etmektedir ve bulgular birbirini destekler niteliktedir.

Katılım boyutunda ele alındığında öğretmenlerin okul yöneticilerinin destek düzeyine ilişkin algılarının katılıyorum düzeyinde olduğu görülmüştür. Ayrıca öğretmenlerin okul yöneticilerinin katılım durumuna ilişkin çoğunlukla olumlu yönde bir destek sağladıklarına dönük olarak cevapları söz konusudur. Bu iki bulgu (nicel ve nitel) birlikte, okullarda katılımın sağlanması yönünden bir sosyal adalet liderliğinin varlığına işaret etmektedir ve bulgular birbirini destekler niteliktedir.

\section{Tartışma, Sonuç ve Öneriler}

Bu bölümde; araştırma bulgularına dayalı olarak sonuçlar tartışılarak sunulmuş ve önerilere yer verilmiştir. Bu bölüm; demografik değişkenlere ilişkin araştırma sonuçları ve "nicel ve nitel 
bulguların birleştirilmesi"ne ilişkin araştırma sonuçları olmak üzere iki ayrı başlık biçiminde ele alınmıştır. Ayrıca bölüm sonunda, varsayım ve sınırıııklara da yer verilmiştir.

\section{Demografik değişkenlere ilişkin araştırma sonuçları}

Demografik değişkenlere ilişkin araştırma sonuçları incelendiğinde; öğretmenlerin okul yöneticilerinin sosyal adalet liderliği düzeyine ilişkin algıları, cinsiyet değişkenine göre anlamlı bir farklıık göstermiştir. Erkek öğretmenlerin okul yöneticilerinin sosyal adalet liderliği düzeyine ilişkin, kadın öğretmenlere göre daha yüksek düzeyde bir algıya sahip oldukları tespit edilmiştir. Bu sonuç, erkek öğretmenlerin okullarda sosyal adalet liderliği kapsamındaki destek, eleştirel bilinç ve katılımın sağlanmasına ilişkin daha olumlu bir görüşe sahip olduklarını göstermektedir. Bu durum, erkeklerin sosyal ilişkilerde daha fazla aktif olmasından ve kabul görmesinden kaynaklanabilir. Kadınların da okullarda sosyal ilişkilerde bulunmaları teşvik edilerek, sosyal adalet liderliğine daha fazla katkı vermeleri sağlanabilir. Araştırma bulgusu, Bozkurt (2018) ve Arslan (2019) tarafından yapılan araştırma bulgularıyla benzerlik göstermektedir. Ayrıca araştırma bulgusu, Gören (2019) tarafından yapılan araştırma bulgularıyla örtüşmemektedir. Bu durum, araştırmalarda kullanılan örneklem grubu farklılığından kaynaklanabilir. Gören (2019) tarafından yapılan araştırmada, kızların okul yöneticilerinin sosyal adalet liderliği düzeyine ilişkin, erkeklere göre daha yüksek düzeyde bir algıya sahip oldukları tespit edilmiştir.

Öğretmenlerin okul yöneticilerinin sosyal adalet liderliği düzeyine ilişkin algıları, medeni durum değişkenine göre anlamlı bir farklılık göstermiştir. Evli öğretmenlerin okul yöneticilerinin sosyal adalet liderliği düzeyine ilişkin, bekâr öğretmenlere göre daha yüksek düzeyde bir algıya sahip oldukları tespit edilmiştir. Bu sonuç, evli öğretmenlerin okullarda sosyal adalet liderliği kapsamındaki destek, eleştirel bilinç ve katılımın sağlanmasına ilişkin daha olumlu bir görüşe sahip olduklarını göstermektedir. Bu durum, evli olanların akrabalık ve dostluğa dönük sosyal ilişkilere daha fazla önem vermelerinden kaynaklanabilir. Bekâr olanların da akrabalık ve dostluğa dönük sosyal ilişkilerde bulunmaları desteklenerek, sosyal adalet liderliğine ilişkin daha fazla farkındalık kazanmaları sağlanabilir. Araştırma bulgusu, Bozkurt (2018) tarafından yapılan araştırma bulgularıyla benzerlik göstermektedir.

Öğretmenlerin okul yöneticilerinin sosyal adalet liderliği düzeyine ilişkin algıları, yaş değişkenine göre anlamlı bir farklılık göstermiştir. 21-30 yaş, 41-50 yaş ile 51 ve üzeri yaş gruplarındaki öğretmenlerin okul yöneticilerinin sosyal adalet liderliği düzeyine ilişkin, 31-40 yaş grubundaki öğretmenlere göre daha yüksek düzeyde bir algıya sahip oldukları tespit edilmiştir. Bu sonuç, 21-30 yaş, 41-50 yaş ile 51 ve üzeri yaş gruplarındaki öğretmenlerin okullarda sosyal adalet liderliği kapsamındaki destek, eleştirel bilinç ve katılımın sağlanmasına ilişkin daha olumlu bir görüşe sahip olduklarını göstermektedir. Bu durum, genç ve ileri yaşta olanların sosyal iletişim ve ilişkilerde daha fazla bulunmalarından ve bu ilişkilere daha fazla önem vermelerinden kaynaklanabilir. Genç orta yaşta olanların da okullarda sosyal iletişim ve ilişkilerde bulunmaları teşvik edilerek, sosyal adalet liderliğine daha fazla önem vermeleri sağlanabilir.

Öğretmenlerin okul yöneticilerinin sosyal adalet liderliği düzeyine ilişkin algıları, öğrenim durumu değişkenine göre anlamlı bir farklılık göstermiştir. Lisans mezunu öğretmenlerin okul yöneticilerinin sosyal adalet liderliği düzeyine ilişkin, lisansüstü mezunu öğretmenlere göre daha yüksek düzeyde bir algıya sahip oldukları tespit edilmiştir. Bu sonuç, lisans mezunu öğretmenlerin okullarda sosyal adalet liderliği kapsamındaki destek, eleştirel bilinç ve katılımın sağlanmasına ilişkin daha olumlu bir görüşe sahip olduklarını göstermektedir. Bu durum, lisans mezunu olanların sosyal ağlara katılımlarının daha fazla olmasından kaynaklanabilir. Lisansüstü mezunu olanların da sosyal ağlara dönük sosyal ilişkilerde bulunmaları desteklenerek, sosyal adalet liderliğine ilişkin daha fazla aktif rol almaları sağlanabilir. Araştırma bulgusu, Bozkurt (2018) ve Arslan (2019) tarafından yapılan 
araştırma bulgularıyla örtüşmemektedir. Bozkurt (2018) ve Arslan (2019) tarafından yapılan araştırmalarda lisansüstü mezunu öğretmenlerin okul yöneticilerinin sosyal adalet liderliği düzeyine ilişkin, lisans mezunu öğretmenlere göre daha yüksek düzeyde bir algıya sahip oldukları tespit edilmiştir. Bu durum, araştırmalarda kullanılan örneklem grubu farklılığından kaynaklanabilir.

\section{“Nicel ve nitel bulguların birleştirilmesi”ne ilişkin araştırma sonuçları}

Öğretmen görüşlerine göre okullarda sosyal adalet liderliğinin yeterli düzeyde/durumda olduğu söylenebilir. Okul yöneticileri sosyal adaleti sağlama bağlamında gerekli biçimde liderlik özelliği göstermektedir. Bu durum da, okullarda etkin bir sosyal adalet mekanizmasının kurulduğuna ve yöneticilerin bu konuda aktif rol oynadıklarına işaret etmektedir. Yöneticiler, okullarda sosyal adaleti ve eşitliği sağlamaktadır. Araştırma bulgusu, Özdemir ve Pektaş (2017), Bozkurt (2018) ve Arslan (2019) tarafından yapılan araştırma bulgularıyla benzerlik göstermektedir. Ayrıca, Bozdoğan ve Sağnak (2011), Taş ve Çetiner (2011), Turhan ve Çelik (2011), Gündüz ve Balyer (2012) tarafından yapılan araştırmalarda da okul yöneticilerinin liderlik yönelimli davranışları yüksek biçimde sergiledikleri tespit edilmiştir. Önceki çalışmalar, sosyal adalet lideri olarak okul müdürünün ihtiyacı olan öğrenci ve öğretmenlerin yanında olduklarını ve onları desteklediklerini belirtmiştir (Theoharis, 2008). Diğer bir araştırmada ise, sosyal adalet lideri olarak okul müdürlerinin okul toplumu ile güvene dayalı bir ilişki kurdukları ve okul toplumunu toplumsal eşitsizliklerin farkına varmaları için bilinçlendirme çabası içerisinde bulundukları tespit edilmiştir (Furman, 2012). Sosyal adalet liderliği ile ilgili Özdemir (2017), Büyükgöze, Şayır, Gülcemal ve Kubilay (2018) ile Gören (2019) tarafından yapılan araştırmalarda ise okul yöneticilerinin sosyal adalet liderliği davranışını orta düzeyde sergiledikleri belirlenmiştir. Bu durum, araştırmalarda kullanılan örneklem grubu farklıı̆ı̆ndan kaynaklanabilir.

Öğretmen görüşlerine göre okullarda sosyal adalet liderliğine ilişkin destek yeterli düzeydedir/durumdadır. Okul yöneticileri eğitim paydaşlarına destek sağlama bağlamında gerekli biçimde sosyal adalet liderliği sergilemektedir. Bu durum da, okullarda etkin bir destek mekanizmasının bulunduğunu ve okul yöneticilerinin desteğin sağlanmasına olumlu yönde katkı sağladıklarını göstermektedir. Yöneticiler, okullarda ihtiyaç duyan eğitim paydaşlarına olumlu yönde destek sağlamaktadır. Araştırma bulgusu, Arslan (2019) tarafından yapılan araştırma bulgularıyla benzerlik göstermektedir. Sosyal adalet liderliği ile ilgili Gören (2019) tarafından yapılan araştırmada ise okul yöneticilerinin destek davranışını orta düzeyde sergiledikleri belirlenmiştir. Bu durum, araştırmalarda kullanılan örneklem grubu farklılığından kaynaklanabilir.

Öğretmen görüşlerine göre okullarda sosyal adalet liderliğine ilişkin eleştirel bilinç yeterli düzeydedir/durumdadır. Okul yöneticileri okulda eleştirel bilincin sağlanması hususunda gerekli biçimde sosyal adalet liderliği sergilemektedir. Bu durum da, okullarda etkili bir eleştirel bilinç sisteminin kurulduğuna ve okul yöneticilerinin eleştirel bilinci sağladığına işaret etmektedir. Yöneticiler, okullarda farklııklara açık ve saygı göstermektedir. Araştırma bulgusu, Arslan (2019) tarafından yapılan araştırma bulgularıyla benzerlik göstermektedir. Ayrıca araştırma bulgusu, YıImaz ve Altınkurt (2011), Şahin, Demir ve Arcagök (2016) ile Büyükgöze ve Yılmaz-Fındık (2018) tarafından yapılan araştırma bulgularıyla örtüşmemektedir. Eleştirel pedagojiye yönelik öğretmen tutumlarını inceledikleri araştırmalarında, öğretmenlerin genel olarak eleştirel pedagojiye dönük tutumları orta düzeyde bulunmuştur. Bu durum, çalışmalarda kullanılan veri toplama araçlarında yer alan maddelerin liderlik boyutundan ziyade eleştirel pedagoji yaklaşımına uygun hazırlanmasından kaynaklanabilir. Sosyal adalet liderliği ile ilgili Gören (2019) tarafından yapılan araştırmada ise okul yöneticilerinin eleştirel bilinç davranışını orta düzeyde sergiledikleri belirlenmiştir. Bu durum, araştırmalarda kullanılan örneklem grubu farklılığından kaynaklanabilir. 
Öğretmen görüşlerine göre okullarda sosyal adalet liderliğine ilişkin katılım yeterli düzeydedir/durumdadır. Okul yöneticileri eğitim paydaşlarının katılımını sağlaması konusunda gerekli biçimde sosyal adalet liderliği göstermektedir. Bu durum da, okullarda aktif bir katılımcı bir yönetim yapısının bulunduğunu ve okul yöneticilerinin katılımı sağladıklarını göstermektedir. Yöneticiler, okullarda katılımcı bir yönetim anlayışını benimsemektedir ve görüşlere önem vermektedir. Araştırma bulgusu, Arslan (2019) tarafından yapılan araştırma bulgularıyla benzerlik göstermektedir. Sosyal adalet liderliği ile ilgili Gören (2019) tarafından yapılan araştırmada ise okul yöneticilerinin katılım davranışını düşük düzeyde sergiledikleri belirlenmiştir. Bu durum, araştırmalarda kullanılan örneklem grubu farklılı̆ıından kaynaklanabilir.

Araştırmada, okullarda sosyal adalet liderliği ve bu kapsamdaki destek, eleştirel bilinç ve katııımın yeterli olduğu bulunmuştur. Bu olumlu gidişatın devam etmesi ve artması için tüm eğitim paydaşlarını bilinçlendirici eğitimler düzenlenebilir. Toplumda dezavantajlı olan kesimlerle okullarda birtakım ortak etkinlikler düzenlenerek, etkin bir sosyal adalet liderliği sağlanabilir. Okullarda farklılıklara saygı uygulamaları, hoşgörü ortamı sağlayarak sosyal adalet liderliğine katkıda bulunabilir. Ayrıca, katılım yoluyla ve görüşlere önem verilerek, alınan kararların sonuçlarının etkililiğinin gösterilmesi yoluyla katılım teşvik edilebilir ve sosyal adalet liderliğinde nitelik artırılabilir.

\section{Varsayım ve sınırlılıklar}

Öğretmenlerin uygulamalara gönüllü olarak katıldıkları varsayılmıştır. Araştırmada kullanılan ölçme araçlarının, okul yöneticilerinin sosyal adalet liderliği davranışlarını ölçmede yeterli olduğu varsayılmıştır. Araştırma uygulamanın yapıldığı Ankara il merkezindeki resmi örgün eğitim kurumu öğretmenleriyle, sosyal adalet liderliği ölçeği ve görüşme formuyla sınırlıdır. 


\section{Kaynakça}

Archer, L., Hutchings, M. ve Ross, A. (2003). Higher education and social class. London: Routledge Farmer.

Arslan, A. (2019). Sosyal adalet liderliği ve etik iklim arasındaki ilişkiye yönelik öğretmen görüşleri. (Yayımlanmamış yüksek lisans tezi). Hacettepe Üniversitesi, Eğitim Bilimleri Enstitüsü, Ankara.

Baker, E. T., Wang, M. C. ve Walberg, H. J. (1995). The effects of inclusion on learning. Educational Leadership, 52(4), 33-35.

Bourdieu, P. ve Passeron, J. C. (1990). Reproduction in education society and culture (2. bs.). London: Sage Publication.

Bozdoğan, K. ve Sağnak, M. (2011). İlköğretim okulu müdürlerinin liderlik davranışları ile öğrenme iklimi arasındaki ilişki. Abant izzet Baysal Üniversitesi Eğitim Fakültesi Dergisi, 11(1), 137-145.

Bozkurt, B. (2018). Sosyal adalet liderliği ile yöneticiye bağlıık ve örgütsel vatandaşlık davranışları arasındaki ilişki. (Yayımlanmamış doktora tezi). Gaziantep Üniversitesi, Eğitim Bilimleri Enstitüsü, Gaziantep.

Brooks, J. S. ve Miles, M. T. (2006). From scientific management to social justice... and back again? Pedagogical shifts in educational leadership, 4(1), 2-15.

Brown, T. A. (2006). Confirmatory factor analysis for applied research. New York: Guilford.

Büyükgöze, H., Şayır, G., Gülcemal, E. ve Kubilay, S. (2018). Examining the relationship between social justice leadership and student engagement among high school students. Çukurova Üniversitesi Eğitim Fakültesi Dergisi, 27(2), 932-961.

Büyükgöze, H. ve Yılmaz-Fındık, L. (2018). Eleştirel pedagojinin eğitim sistemindeki görünümü: Öğretmenler üzerine bir çalışma. Illköğretim Online, 17(3), 1336-1352.

Büyüköztürk, Ş. (2013). Sosyal bilimler için veri analizi el kitabı. Ankara: Pegem.

Creswell, J. W. ve Clark, V. P. L. (2018). Karma yöntem araştırmaları tasarımı ve yürütülmesi (Y. Dede \& G. S. B. Demir, Çev. Eds.). Ankara: Anı.

DeMatthews, D. ve Mawhinney, H. (2014). Social justice leadership and inclusion: Exploring challenges in an urban district struggling to adres inequalities. Educational Administration Quarterly, 50(5), 844-881.

Finn, J. D. (1993). School engagement and students at risk. Washington DC: National Center for Education Sciences.

Finn, J. D. ve Rock, D. A. (1997). Academic success among students at risk for school failure. Journal of Applied Psychology, 82(2), 221-234.

Fraser, K. (2012). Exploring the leadership practices of social justice leaders at urban charter schools. Doktora Tezi. University of San Francisco.

Freire, P. (2005). Pedagogy of the oppressed (30th eds.). New York: Continuum International Publishing Group Inc.

Furman, G. (2012). Social justice leadership as praxis: Developing capacities through preparation programs. Educational Administration Quarterly, 48(2), 191-229.

Gewirtz, S. (1998). Conceptualizing social justice in education: Mapping the territory. Journal of Education Policy, 13, 469-484.

Gewirtz, S. ve Cribb, A. (2002). Plural conceptions of social justice: Implications for policy sociology. Journal of Education Policy, 17(5), 499-509.

Gören, S. Ç. (2019). Sosyal adalet liderliği, okul yaşam kalitesi ve okula aidiyet duygusu ilişkisi. (Yayımlanmamış doktora tezi). Hacettepe Üniversitesi, Eğitim Bilimleri Enstitüsü, Ankara.

Gündüz, Y. ve Balyer, A. (2012). Okul müdürlerinin etkili liderlik davranışlarının incelenmesi. Kuramsal Eğitim Bilim Dergisi, 5(2), 237-253.

Hurst, C. (2012). Social inequality: Forms, causes, and consequences (8. ed.). Boston: Pearson.

Jordan, B. (1998). The new politics of welfare. London: Sage.

Katzman, L. (2007). High-stakes testing. In A. Bursztyn (Eds.), The praeger handbook of special education (ss. 127-129). Westport; Praeger.

Marshall, C. ve Oliva, M. (2006). Leadership for social justice: Making revolutions in education. Boston: Pearson Education.

McCabe, N. C. ve McCarthy, M. M. (2005). Educating school leaders for social justice. Educational Policy, 19(1), 201-222.

McKenzie, K. B., Christman, D. E., Hernandez, F., Fierro, E., Capper, C. A., Dantley, M., Gonzalez, M. L., McCabe, N. C. ve Scheurich, J. J. (2008). From the field: A proposal for educating leaders for social justice. Educational Administration Quarterly, 44(1), 111-138. 
McWhirter, E. H. (1997). Perceived barriers to education and career: Ethnic and gender differences. Journal of Vocational Behavior, 50, 124-140.

MEB (2020). 2018-2019 öğretim yılı eğitim istatistikleri. Erişim Adresi (28.04.2020): http://ankara.meb.gov.tr/www/egitim-istatistikleri/icerik/24

Oakes, J., Quartz, K. H., Ryan, S. ve Lipton, M. (2000). Becoming good American schools. Phi Delta Kappan, 81(8), 568-576.

Oplatka, I. (2010). The place of "social justice" in the field of educational administration: A journal based historical overview of emergent area of study. I. Bogotch ve C. M. Shields (Ed.), International handbook of educational leadership and social justice, Vol 1 (p. 15-36). London: Springer.

Özdemir, M. ve Kütküt, B. (2015). Sosyal adalet liderliği ölçeği'nin geliştirilmesi: Geçerlik ve güvenirlik çalışması. Ahi Evran Üniversitesi Kırşehir Eğitim Fakültesi Dergisi, 16 (3), 201-218.

Özdemir, M. (2017). Sosyal adalet liderliği okula yönelik tutum ve okul bağlılığı arasındaki ilişkilerin incelenmesi. Eğitim ve Bilim, 42(127), 267-281.

Özdemir, M. ve Pektaş, V. (2017) . Sosyal adalet liderliği ve okul akademik iyimserliği ilişkisinin öğretmen görüşlerine göre incelenmesi. Ege Eğitim Dergisi, 18(2), 576-601.

Şahin, Ç. Demir, M. ve Arcagök, S. (2016). Öğretmen adaylarının eleştirel pedagoji ilkelerine yönelik yaklaşımlarının çeşitli değişkenler açısından incelenmesi. Erzincan Üniversitesi Eğitim Fakültesi Dergisi, 18(2), 1187-1205.

Taş, A. ve Çetiner, A. (2011). Ortaöğretim okulu müdürlerinin dönüşümcü liderlik davranışlarını gerçekleştirme durumlarına ilişkin öğretmen görüşleri. Türk Eğitim Bilimleri Dergisi, 9(2), 369-392.

Theoharis, G. (2007). Social justice educational leaders and resistance: Toward a theory of social justice leadership. Educational Administration Quarterly, 43(2), 221-258.

Theoharis, G. (2008). Woven in deeply: Identity and leadership of urban social justice principals. Education and Urban Society, 41(1), 3-25.

Turhan, M. ve Çelik, V. (2011). Ortaöğretim okulu müdürlerinin dönüşümcü liderlik davranışlarını gerçekleştirme durumlarına ilişkin öğretmen görüşleri. Türk Eğitim Bilimleri Dergisi, 9(2), 369-392.

Yıldırım, A. ve Şimşek, H. (2016). Sosyal bilimlerde nitel araştırma yöntemleri. Ankara: Seçkin.

Yılmaz, K. ve Altınkurt, Y. (2011). Öğretmen adaylarının eleştirel pedagoji ile ilgili görüşleri. Ahi Evran Üniversitesi Eğitim Fakültesi Dergisi, Cilt 12,(3), 195-213.

Not: Bu araştırmanın gerçekleştirilebilmesi için “Etik Kurul Onayı (Hacettepe Üniversitesi Rektörlük Makamının 14.07.2020 tarihli ve 35853172-600/00001156231 sayılı yazııı)" alınmıştır; bu araştırma, Hacettepe Üniversitesi Senatosu Etik Komisyonunun 23 Haziran 2020 tarihinde yapmış olduğu toplantıda incelenmiş olup, etik açıdan uygun bulunmuştur. Ayrıca çalışma grubu öğretmenlerine araştırmaya katılım için onam vermeleri ve araştırmanın gönüllülük esaslı yürütülmesi amacıyla Hacettepe Üniversitesi Senatosu Etik Komisyonu Bilgilendirilmiş Onam Formu imzalatılmıştır. 